International Journal of Agriculture, Environment and Bioresearch

Vol. 06, No. 05; 2021

ISSN: $2456-8643$

\title{
PARASITES IN FRESHWATER FISH ALONG VALUE CHAIN OF MEDINA COURA MARKET IN BAMAKO, MALI
}

\author{
Aminata Sissoko ${ }^{1,2}$, Fassé Samakée ${ }^{3}$, Kwaku Tano-Debrah ${ }^{1}$, Angela Parry-Hanson Kunadu ${ }^{1}$, Ibrahima \\ Mariko $^{2}$, Felix Kwashie Madilo ${ }^{1,4}$, Boubacar Madio dit Aladiogo Maïga ${ }^{2}$, Saidou Tembely ${ }^{2}$ \\ ${ }^{1}$ Department of Nutrition and Food Science, University of Ghana, Legon, Accra, Ghana \\ ${ }^{2}$ Central Veterinary Laboratory (CVL), Bamako, Mali \\ ${ }^{3}$ Microbiology and Microbial Biotechnology Research Laboratory, Departement of Biology, University of Sciences, \\ Techniques and Technology of Bamako, Bamako, Mali \\ ${ }^{4}$ Department of Food Science and Technology, Faculty of Science and Technology, Ho Technical University, Ho,
} Ghana

https://doi.org/10.35410/IJAEB.2021.5669

\begin{abstract}
Parasitic infestations of 120 specimens of three freshwater fish species, comprising of Lates niloticus (44), Clarias anguillaris (40) and Oreochromis niloticus (36) sold at the Medina Coura market in Mali, were investigated. The fresh fish samples were taken during two seasons (cold and hot) in four fish production areas (Niger Central Delta in Mopti, Selingue, Manantali, Markala) and from the Medina Coura market. In each area, the samples were taken at three points (capture, landing and sale), using standard methods and procedures. A dissection was performed on each fish sample and the conditions of the skin, flesh, gills and abdominal cavity were observed for the detection of infestations. Three species of parasites were detected, namely, Salmincola edwardsii (crustacea) at the gills, and Philonema sp. and Raphidascaris sp. (Nematodes) in the abdominal cavity. An overall prevalence of 10\% (12/120) parasitic infestation was observed. Prevalence was lower during the cold season, (5.2\% of the fish) than in the hot season (14.5\%). The highest prevalence of infestation was observed in Oreochromis niloticus (Tilapia) at $16.7 \%$ followed by Lates niloticus (Nile Perch) (9.1\%) and Clarias anguillaris (Catfish) (5.0\%). Research finding showed that infection prevalence and diversity of parasites were relatively low.
\end{abstract}

Keywords: Parasites, fresh fish, freshwater, Niger river, Senegal river.

\section{INTRODUCTION}

Fish is one of the best sources of animal protein for human health. According to the Food and Agriculture Organization (Djiré, 2007), fish is an important source of nutrients, because of its protein, vitamin A and D, phosphorus, lysine, sulphur and essential amino acids composition. Cholesterol level is also low in fish meat (Fagbenro et al., 2005; Aremu et al., 2013; Ayeloja et al., 2013; Oladipo and Bankole, 2013; Khalili Tilami \& Sampels, 2017).

All fish species are vulnerable to various parasitic infections depending on the species of fish and the type of watercourses inhabited (Oniye et al., 2004). Various parasites are associated with freshwater fish; they cause morbidity, mortality and economic losses in Africa (Oniye et al., 2004; Ayanda, 2009). When the parasite infects the fish, they usually cause chronic damage that can be tolerated by the fish (Bamidele, 2015). Factors favoring parasitic infection in fish include reduction of the oxygen content of water, an increase of organic matter and poor environmental 
conditions (Edema et al., 2008). Fresh or undercooked infected fish can cause zoonotic infections, which are a real public health problem (Dorny et al., 2009; Bouchriti et al., 2014).

In Mali, food safety risks associated with the presence of parasites in fishery products are poorly known by professionals and consumers. Parasitic fish must be rejected, if it is not sufficiently cooked since its penetration into the upper digestive tract may be a threat to the health of the consumer. Therefore, it is important to sensitize the population about fish hygiene practices to minimize the impact of the parasite on public health.

The present study was conceived to determine the prevalence and seasonal distribution of parasites in economically important and popular freshwater fish species: Lates niloticus, Clarias anguillaris, and Oreochromis niloticus sold on the Medina Coura market in Bamako.

\section{MATERIAL AND METHODS} Study Area

In Mali, fishing is practiced in almost all water bodies in the country. It is the largest freshwater fishing country in the world. Fishing is practiced in two river basins lakes, ponds and flood plains (Quensiere, 1994). The main fishing areas are Central Delta of Niger (about 80\% of total freshwater fish production), Selingue Lake, Markala Lake and Manantali Lake (Figure1).

The Central Niger Delta is a vast region of about $30000 \mathrm{~km}^{2}$, in the Center of Mali. The annual production varies between 45000 and 100000 tones according to the importance of the floods (Quensiere, 1994). About $140 \mathrm{~km}$ South of Bamako, Selingue The dam is $348 \mathrm{~m}$ long and the lake covers $409 \mathrm{~km}^{2}$ and contains 2.2 billion $\mathrm{m}^{3}$ of water. However, its depth does not exceed 20 m (Paugy \& Leveque, 2006). By year, the lake produces about 4000 tons of fish (Miller, 2006). Manantali Lake provides both irrigation and hydroelectric power. $208 \mathrm{~m}$ long with an area of up to $500 \mathrm{~km} 2$, it contains 11 billion $\mathrm{m}^{3}$ of water. The depths of the medium and maximum dam are respectively $20 \mathrm{~m}$ and $50 \mathrm{~m}$ (Miller, 2006). Per year, fish production is about 1,500 tons, Markala dam was built in 1943, located $250 \mathrm{~km}$ downstream from Bamako in Mali to store water for irrigation (Miller, 2006). The "Office du Niger" zone, aims to develop agriculture.

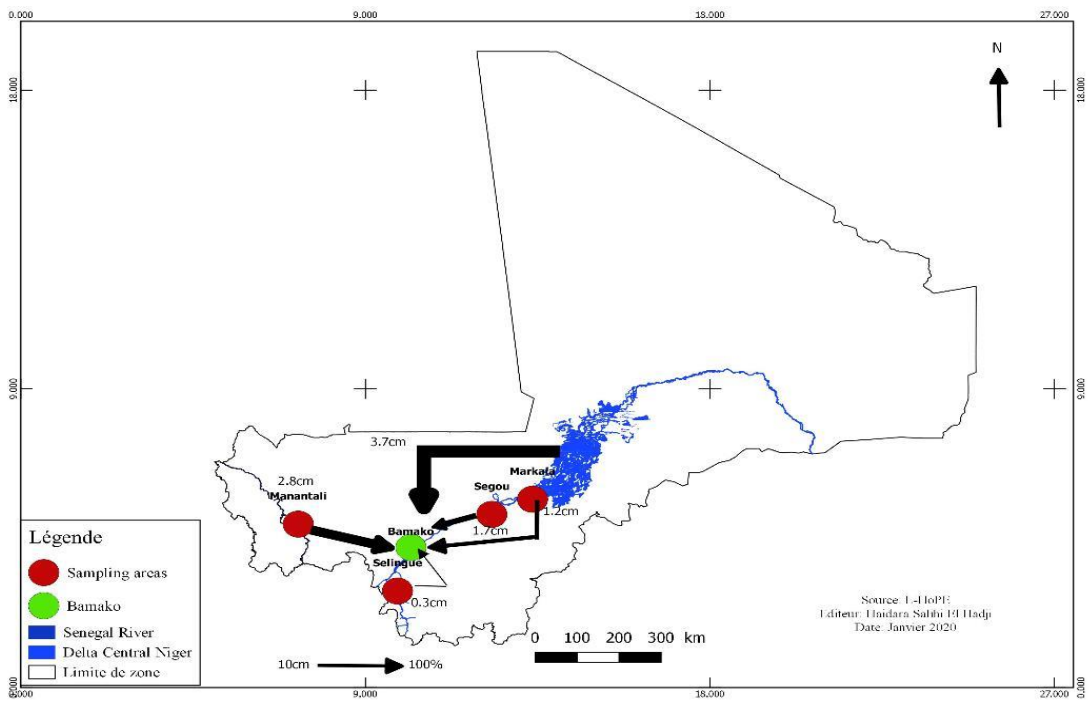

Figure 1: Map showing the different sampling points 


\section{Sampling procedure}

Three freshwater fish species sold on the Medina Coura market, a major fish market in Bamako were sampled for this study. These were Nile perch: Lates niloticus, vernacular name in Bambara (Saalen); Catfish: Clarias anguillaris, vernacular name in Bambara (Maanogo Blen) and Tilapia: Oreochromis niloticus, vernacular name in Bambara (N'teben fin). These fishes were selected because of their economic importance and popularity in Mali. All samples were obtained from harvest and landing sites, from four (4) areas (Selingue, Manantali, Markala, Mopti) and a selling site in Medina Coura market.

Two (2) specimens of each of the three (3) species of fish were sampled for parasitic assessments.

\section{Sample size}

The Samples were taken during the cold season (December - February) and the hot season (March-May) (table1). 120 randomly selected fresh specimens of 44 Lates niloticus, 40 Clarias anguillaris, and 36 Oreochromis niloticus, were purchased at capture point, at the landing point where the fishes are packed for the market and at Medina Coura market, which is selling point. The samples were transported directly to the helminthology laboratory of the Central Veterinary Laboratory of Bamako in a cooler, where they were subjected to parasite analyses.

Table 1: Distribution of fish species collected by sampling site

\begin{tabular}{llllll}
\hline Areas & Seasons & L. niloticus & C. anguillaris & O. niloticus & Total \\
Selingue & Cold & 4 & 4 & 4 & 30 \\
\multirow{3}{*}{ Manantali } & Hot & 6 & 6 & 6 & \\
& Cold & 6 & 4 & 4 & 30 \\
Markala & Hot & 6 & 6 & 4 & \\
& Cold & 6 & 4 & 4 & 26 \\
\multirow{2}{*}{ Mopti } & Hot & 4 & 4 & 4 & \\
& Cold & 6 & 6 & 6 & 34 \\
\hline Total & Hot & 6 & 6 & 4 & \\
\hline
\end{tabular}

The parasitological examination was made on fish by its lateral decoupage through the mouth. The alimentary canals were removed and cut into different parts, such as the stomach, large intestine, and small intestine. This was done on a petri dish with normal saline for parasite recovery. The intestines were carefully cut to promote the emergence of parasites.

The macroscopic examination involved observation of the general state of each sample, the level of deterioration of the skin, the state of the gills by the appreciation of the color, and the signs of attack. The fish were also examined under the Olympus BO61 binocular magnifier for cysts, larvae in the flesh and the abdominal cavity. The results were analysed for prevalence according to Margolis et al., 1982:

Prevalence $(\%)=$ number of infected hosts $\times 100 /$ total number of hosts examined

Crustacea identification was based on morphological features according to Yamaguti, 1963. 
Vol. 06, No. 05; 2021

ISSN: $2456-8643$

\section{Data analysis method}

The one-way analysis of variance (ANOVA) was applied to determine the significance of changes in the prevalence of infection between the two seasons in 4 areas of the study period. The percentages of infestation were compared by the chi-square $\chi^{2}$ test.

SPSS 23.0 Software was used for data analysis with a confidence interval of $95 \%$.

\section{RESULTS}

Of the 120 fish samples analyzed, parasites were present in fishes at the capture points, the landing point at Selingue, Manantali, Markala, Mopti and at the selling point Medina Coura market.

\section{Prevalence of infected fish species}

Parasite infestation has varied from one species to another. A low infestation rate was observed $(10 \%)$ in our fish samples. The highest parasite infestation was observed in Oreochomis niloticus with an infestation rate of $16.7 \%$ followed by Lates niloticus $9.1 \%$ and Clarias anguillaris $5.0 \%$ during both seasons. A no significant difference in prevalence between fish species examined was observed chi-square $\chi^{2}=0.87$, ( $p>0.05$ ). It showed a lower variation of prevalence of parasites among the fish species in this study

Table 2: Prevalence of parasites by fish species

\begin{tabular}{llll}
\hline Fish species & Number examined & Number infected & Prevalence (\%) \\
\hline Lates niloticus & 44 & 4 & 9,1 \\
Clarias anguillaris & 40 & 2 & 5 \\
Oreochromis niloticus & 36 & 6 & 16,7 \\
\hline Total & 120 & 12 & 10 \\
\hline
\end{tabular}

Variation of parasitism according to the organs of the fish and areas of sampling

The skin, flesh, gills, and abdominal cavity were observed macroscopically. The most affected internal organs of the fish were the gills with the presence of Salmincola edwardsii (crustaceans) and the abdominal cavity with the presence of nematodes Rhaphidascaris $s p$. and Philonema sp.. These parasites belonging to different taxonomic groups were recovered from 12 positives sampled fish.

The frequency distribution of parasites among the three fish species (Lates niloticus, Clarias anguillaris, and Oreochromis niloticus) per sampling area is presented in Table 3. Philonema sp. (12.5\%) was the most frequently found parasite in Markala followed by Raphidascaris sp. Which were recovered from the abdominal cavity in $10 \%$ and $8.82 \%$ respectively of fishes sampled in Selingue and Mopti. Salmincola edwardsii was found in the gills at $4.16 \%$ of the fish sampled at Markala. These results show that there is no significant difference between parasite variation and prevalence at the sampling areas $\left(\chi^{2}=0.821, p>0.05\right)$. 
Vol. 06, No. 05; 2021

ISSN: $2456-8643$

Table 3: Prevalence of parasites per infected organs and areas

\begin{tabular}{llllllllll}
\hline Parasites & Inf. Organs & \multicolumn{2}{l}{ Selingue } & \multicolumn{2}{l}{ Manantali } & \multicolumn{2}{l}{ Markala } & \multicolumn{2}{l}{ Mopti } \\
& & NOP & $\mathrm{P}(\%)$ & NOP & $\mathrm{P}(\%)$ & NOP & $\mathrm{P}(\%)$ & NOP & $\mathrm{P}(\%)$ \\
\hline Raphidascaris sp. & Abd. cavity & 3 & 10 & 1 & 3.57 & 0 & 0 & 3 & 8.82 \\
Philonema sp. & Abd. cavity & 0 & 0 & 0 & 0 & 3 & 12.5 & 2 & 5.88 \\
Salmincolaedwardsii & Gill & 0 & 0 & 1 & 4.16 & 0 & 0 & 0 & 0 \\
\hline
\end{tabular}

Key: NOP - Number of positive; $P$-Prevalence; Inf. -Infected; Abd-Abdominal

\section{Seasonal variation offish parasites per sampling areas}

To assess the seasonal prevalence of parasites in the cold and hot seasons, 58 and 62 samples were examined for hot and cold seasons respectively of which $3(5.17 \%)$ and 9 $(14.52 \%)$ were infested respectively.

The parasite frequency distribution per season and the per area have shown that the high parasite infestation was observed during the hot season in Selingue with $25 \%$ prevalence followed by Mopti 20\%, Manantali 16.66\%, and Medina Coura 1.66\%. In the cold season fish sampled from the selling point had parasite infestation rate of $10 \%$, followed by Manantali and Markala with $8.33 \%$ in a landing point. The seasonal variation on parasites of fish species samples per area was not significantly different $\left(\chi^{2}=0.363, p>0.05\right)$ from each other during the different seasons.

Table 4: Prevalence of fish infested with parasites per areas and season

\begin{tabular}{lllll}
\hline Seasons & Sampling Site & \multicolumn{2}{l}{ No. Examined No. Infected } & Prevalence (\%) \\
Cold season & Selingue & 12 & 0 & 0 \\
& Manantali & 12 & 1 & 8.33 \\
& Markala & 12 & 1 & 8.33 \\
& Mopti & 12 & 0 & 0 \\
& MCM & 10 & 1 & 10 \\
& Total & $\mathbf{5 8}$ & $\mathbf{3}$ & $\mathbf{5 . 1 7}$ \\
Hot season & Selingue & 12 & 3 & 25 \\
& Manantali & 12 & 2 & 16.66 \\
& Markala & 12 & 0 & 0 \\
& Mopti & 10 & 2 & 20 \\
& MCM & 16 & 1 & 1.60 \\
TOTAL & Total & $\mathbf{6 2}$ & $\mathbf{9}$ & $\mathbf{1 4 . 5 2}$ \\
\hline
\end{tabular}

Key: Medina Coura Market

\subsection{Prevalence of infected fish species at each sampling point}

Table 5 shows the prevalence of each species of fish in each area at the sampling points. Parasite prevalence varied from one fish species to another. The highest prevalence of the parasite in Oreochromis niloticus was observed at Mopti at the selling point (50\%) followed by 
Vol. 06, No. 05; 2021

ISSN: $2456-8643$

Lates niloticus $25 \%$ while the other species of fish have a prevalence of $0 \%$ at the same point of sale.

Table 5: Prevalence of infected fish species at each sampling point

\begin{tabular}{|c|c|c|c|c|c|c|c|c|c|c|}
\hline \multicolumn{2}{|c|}{ Sampling Site Fish Species } & \multicolumn{3}{|c|}{ Capture point } & \multicolumn{3}{|c|}{ Landing point } & \multicolumn{3}{|c|}{ Selling point } \\
\hline & & $\mathrm{NE}$ & $\mathrm{NI}$ & $\mathrm{P}(\%)$ & $\overline{\mathrm{NE}}$ & NI & $\mathrm{P}(\%)$ & $\overline{\mathrm{NE}}$ & NI & $\mathrm{P}(\%)$ \\
\hline \multirow[t]{3}{*}{ Selingue } & L. niloticus & 4 & 0 & 0 & 4 & 1 & 25 & 2 & 0 & 0 \\
\hline & C. anguillaris & 4 & 0 & 0 & 4 & 0 & 0 & 2 & 0 & 0 \\
\hline & O. niloticus & 4 & 1 & 25 & 4 & 1 & 25 & 2 & 0 & 0 \\
\hline \multirow[t]{3}{*}{ Manantali } & L. niloticus & 4 & 0 & 0 & 4 & 0 & 0 & 4 & 0 & 0 \\
\hline & C. anguillaris & 4 & 0 & 0 & 4 & 0 & 0 & 2 & 0 & 0 \\
\hline & O. niloticus & 4 & 0 & 0 & 4 & 1 & 25 & 0 & 0 & 0 \\
\hline \multirow[t]{3}{*}{ Markala } & L. niloticus & 4 & 0 & 0 & 4 & 0 & 0 & 2 & 0 & 0 \\
\hline & C. anguillaris & 4 & 1 & 25 & 4 & 1 & 25 & 0 & 0 & 0 \\
\hline & O. niloticus & 4 & 1 & 25 & 4 & 0 & 0 & 0 & 0 & 0 \\
\hline \multirow[t]{3}{*}{ Mopti } & L. niloticus & 4 & 1 & 25 & 4 & 1 & 25 & 4 & 1 & 25 \\
\hline & C. anguillaris & 4 & 0 & 0 & 4 & 0 & 0 & 4 & 0 & 0 \\
\hline & O. niloticus & 2 & 0 & 0 & 4 & 0 & 0 & 4 & 2 & 50 \\
\hline Totat & & 42 & 4 & 9.5 & 44 & 5 & 11.4 & 20 & 3 & 11.5 \\
\hline
\end{tabular}

Key: $N E-$ Number examined; $N I-$ Number infected; $P$-Prevalence

\section{DISCUSSION}

Our study revealed an overall rate of parasite infestation of $10 \%$ in Lates niloticus, Clarias anguilaris, Oreochromis niloticus species. The preliminary investigation of the parasite fauna of fish in Okhuo River in Benin City, Nigeria done by obtained $6.94 \%$ infestation rate. These were rather very low as compared to other similar work such as(Amare et al., 2014a)who reported $47.8 \%$ prevalence of parasites, in Lake Lugo (Hayke), Northeast Ethiopia, and Olofintoye (2006) who observed $62.6 \%$ in his study on a parasitofauna in some freshwater fish species in Ekiti States, Nigeria suggesting that the distribution of parasites can be varied from one habitat to the other due to host parasite relationship and abiotic factors like dissolved oxygen, temperature and $\mathrm{pH}$. This depends on a number of factors which include among other things, the nature of the water which is reflected in the human use and the endemicity of infection in the area.

The prevalence of parasites was higher in Oreochromis niloticus $16.7 \%$ followed by Lates niloticus $9.1 \%$ and Clarias anguillaris 5\%. In the present study prevalence finding are lower than Amare et al., 2014b in Lake Lugo (Hayke), Northeast Ethiopia who found a prevalence rate of $50.22 \%$ in Oreochromis species.

The study showed that, the prevalence of nematodes was higher than crustacea. The higher rate of nematode infestation may be due to the low host specificity of the adult stage of these parasites, or the ability of different genera and species of the nematode to infect the fish species studied, and the availability of the different host required for the completion of the life cycle of these parasites Yamaguti, 1963. 
The prevalence of Salmincola edwardsii is $4.16 \%$ observed only in Manantali on Oreochromis niloticus in the gills. Salmincola edwardsii belong to the Arthropoda Phylum, subphylum Crustacea, family Lernaeopodidae, and are commonly called "gill lice" or "gill fly" Alteen, 2009 and Boucenna et al., 2015 also detected the presence of this parasite in the gills. They inferred that this parasite can cause swelling around the site of attachment of the bubble, with heavy parasite loads. The presence of this crustacean reduces the feeding activity of the host fish by weakening the host fish and negatively affecting its weight gain, reproduction, and therefore growth. According to Folefack et al.,(2019a) the frequency of gill infestation by these parasites is may be because gills have a close relationship with the aquatic environment where fish live. It is observed that Oreochromis niloticus collected at the point of sale in the Mopti area during the hot season has a much higher prevalence (50\%) than other species. These parasites are capable of absorbing nutrients, vitamins, micro and macronutrients in the digestive tract of fish. According to Bichi \& Dawaki (2010), these parasites develop metabolic wastes that have a negative impact on the physiology and reproduction of fish.

\section{CONCLUSION}

The study allowed us to determine the parasites present in the 5 areas (Selingue, Manantali, Markala, Mopti, and Medina Coura market) for freshwater fresh fishes from harvest capture to sale. The prevalence of parasites among fish in rivers in Mali was low.

However, parasites should not be neglected in fish, they are important enough to reduce the number of fish per death, reduce their market value, and may cause human infections when live cysts or matured parasites are ingested.

\section{DECLARATION}

Funding: This study was funded by Borlaug High Education for Agricultural Research (BHEARD). The authors are also grateful to Central Veterinary Laboratory (CVL), Mali where the laboratory analysis was carried out and the collaborating institution, Department Nutrition and Food Science, University of Ghana.

Conflict of interest: Not applicable

Ethical approval: Ethical clearance was obtained from the Ethics Committee of the National Institute of Research in Public Health (INRSP). The provisions relating to ethics have been observed and respected according to the provisions of Law No. 2013-015 of 21 May 2013 on the Protection of Personal Data in the Republic of Mali and the Declaration of 'Helsinki 5 version 2013 to establish fact sheet, a free and informed consent form.

Consent for publication: Not applicable

Consent to participate: Written informed consent was obtained from the participants.

Availability of data and material: All available data supporting the study have been included in the write-up

Code of availability: Not applicable 
Vol. 06, No. 05; 2021

ISSN: $2456-8643$

\section{AUTHOR CONTRIBUTION}

Aminata Sissoko designed the topic, collected data, and wrote the manuscript, while Fassé Samaké, Tano Debrah Kwaku, and Angela Parry-Hanson Kunadu approved the topic, supervised and reviewed the manuscript, Felix Kwashie Madilo and Boubacar Madio dit Aladiogo Maïga ${ }^{1}$ conducted the data analysis, and formatted the manuscript. Ibrahima Mariko conducted the laboratory analysis.

\section{REFERENCES}

Alteen, N. (2009). Prevalence and intensity of Salmincola edwardsii on brook trout, Salvelinus fontinalis, in the Western Brook system of Gros Morne National Park, Newfoundland and Labrador, Canada [MS Thesis]. Memorial University of Newfoundland.

Amare, A., Alemayehu, A., \& Aylate, A. (2014a). Prevalence of Internal Parasitic Helminthes Infected Oreochromis niloticus (Nile Tilapia), Clarias gariepinus (African Catfish) and Cyprinus carpio (Common Carp) in Lake Lugo (Hayke), Northeast Ethiopia. Journal of Aquaculture Research \& Development, 5(3), Article 3. https://doi.org/10.4172/2155-9546.1000233.

Amare, A., Alemayehu, A., \& Aylate, A. (2014b). Prevalence of Internal Parasitic Helminthes Infected Oreochromis niloticus (Nile Tilapia), Clarias gariepinus (African Catfish) and Cyprinus carpio (Common Carp) in Lake Lugo (Hayke), Northeast Ethiopia. Journal of Aquaculture Research \& Development, 5(3). https://doi.org/10.4172/2155-9546.1000233.

Aremu, M., Namo, S., Salau, R., Agbo, C., \& Hashim, I. (2013). Smoking Methods and Their Effects on Nutritional Value of African Catfish (Clarias gariepinus). The Open Nutraceuticals Journal, 6, 105-112. https://doi.org/10.2174/1876396020130830003.

Ayanda, O. (2009). Comparison of parasitic helminthes infection between the sexes of Clarias gariepinus from Asa dam Ilorin, north-central Nigeria. Scientific Research and Essay, 4, 357360.

Ayeloja, A. A., George, F., Dauda, T., Adeyemi, J., \& Moshood, P. (2013). Nutritional comparison of captured Clarias gariepinus and Oreochromis niloticus. 1 (1); International Research Journal of Natural Sciences, 1(1), 9-13.

Bamidele, A. (2015). A two fish species study of the parasitic helminth fauna of Synodontis filamentosus (boulenger, 1901) and Calamoichthys calabaricus (Smith, 1865) from Lekki Lagoon, Lagos, Nigeria. Ife Journal of Science, 17(1), 12.

Bichi, A., \& Dawaki, S. (2010). A survey of ectoparasites on the gills, skin and fins of oreochromis Niloticus at Bagauda fish farm, Kano, Nigeria. Bayero Journal of Pure and Applied Sciences, 3. https://doi.org/10.4314/bajopas.v3i1.58720.

Boucenna, I., Chahinez, B., Kaouachi, N., Amel, A., Menasria, A., Maazi, M.-C., Barour, C., \& Bensouilah, M. (2015). L'infestation de la population de Cyprinus Carpio (Linnaeus, 1758) par les copépodes parasites dans le barrage Foum El Khanga (Souk-Ahras, Algérie). 163-179.

Bouchriti, N., Triqui, R., Lamane, H., Hamouda, A., \& Karib, H. (2014). Parasitisme dans la filière des produits de la pêche au Maroc: Éléments d'évaluation et de gestion du risque [Revue Marocaine des Sciences Agronomiques et Vétérinaires].

Djiré, M. (2007). Les paysans maliens exclus de la propriété foncière? (Dossier no. 144; p. 28). iied.

Dorny, P., Praet, N., Deckers, N., \& Gabriël, S. (2009). Emerging food-borne parasites. Veterinary Parasitology, 163, 196-206. https://doi.org/10.1016/j.vetpar.2009.05.026 
Edema, C. U., Okaka, C. E., Oboh, I. P., \& Okogub, B. O. (2008). A preliminary study of parasitic infections of some fishes from Okhuo River, Benin City, Nigeria. International Journal of Biomedical and Health Sciences, 4(3), 6. https://doi.org/IJBHS 2008053/4302

Fagbenro, O., Akinbulumo, M., Adeparusi, O., \& Raji, A. (2005). Flesh Yield, Waste Yield, Proximate and Mineral Composition of Four Commercial West African Freshwater Food Fishes. Journal of Animal and Veterinary Advances.

Folefack, G., Kengne, C., Dongmo, B., \& Fomena, A. (2019a). Prevalence and Mean Intensity of Myxobolus spp. Parasitizing Oreochromis niloticus in Cameroon. International Journal of Biology, 11, 35. https://doi.org/10.5539/ijb.v11n2p35.

Folefack, G., Kengne, C., Dongmo, B., \& Fomena, A. (2019b). Prevalence and Mean Intensity of Myxobolus spp. Parasitizing Oreochromis niloticus in Cameroon. International Journal of Biology, 11, 35. https://doi.org/10.5539/ijb.v11n2p35.

Khalili Tilami, S., \& Sampels, S. (2017). Nutritional Value of Fish: Lipids, Proteins, Vitamins, and Minerals. Reviews in Fisheries Science \& Aquaculture, 26(2), 1-11. https://doi.org/10.1080/23308249.2017.1399104.

Margolis, L., Esch, G., Holmes, J., Kuris, A., \& Schad, G. A. (1982). The Use of Ecological Terms in Parasitology (Report of an Ad Hoc Committee of the American Society of Parasitologists). The Journal of Parasitology, 68, 131. https://doi.org/10.2307/3281335

Miller, J. (2006). The potential for development of aquaculture and its integration with irrigation within the context of the FAO Special Programme for Food Security in the Sahel (pp. 61-74) [In M. Halwart \& A.A. Van Dam, Eds].

Olofintoye, L. (2006). Parasitofauna in Some Freshwater Fish Species in Ekiti State, Nigeria. Pakistan Journal of Nutrition, 5(4), 359-362. https://doi.org/10.3923/pjn.2006.359.362

Oniye, S., Adebote, D., \& Ayanda, O. I. (2004). Helminth parasites of Clarias gariepinus (Teugels) in Zaria, Nigeria. Journal of Aquatic Sciences, 19(2), 71-75. https://doi.org/10.4314/jas.v19i2.20027

Paugy, D., \& Leveque, C. (2006). Les poissons des eaux continentales africaines Diversité, écologie, utilisation par l'homme (INSTITUT DE RECHERCHE POUR LE DÉVELOPPEMENT).

Quensiere, J. (1994). La pêche dans le Delta Central du Niger (Vol. 1). Karthala. 